\title{
"Localism" as an approach to community participation in Australian water planning
}

\author{
P. L. Tan \\ Griffith University, Australia
}

\begin{abstract}
Sharing of water between competing uses of surface and groundwater systems across Australia is based on water plans. Based on adaptive management, planning involves the use of participatory processes to achieve a balance between consumptive and in-stream uses of water. Tensions between different stakeholders and values are particularly evident where overallocated water systems are required to be returned to an environmentally sustainable level of extraction, as shown in current processes for a Basin Plan in the Murray-Darling. Parliamentary enquiries have called for the incorporation of "local" approaches in water planning to ease these tensions. Two recent projects identify barriers and bridges to collaborative water planning, and in a variety of contexts, trial practical tools to address issues identified by stakeholders and agencies. Major findings include identification of factors that improve community confidence of plans. These results have implications for water planning in other countries especially where the science is contested, social values are uncertain and communities diverse.
\end{abstract}

Keywords: water allocation, water planning, participatory processes, sustainability, Australia, Murray-Darling Basin.

\section{Introduction}

With a record drought occurring in the recent past, Australians are well aware of the importance of water. The National Water Initiative (NWI) [1] is the high level policy document for its management, leaving implementation to state jurisdictions or regional multi-state and Commonwealth partnerships, such as the Murray-Darling Basin Authority (MDBA). A range of matters are to be 
addressed, chief of which is overuse of water, and the main mechanism for this is water planning at a regional or catchment scale.

To build confidence in water planning, and to provide for transparency in decision-making, the NWI endorses community participation. Although legislation in all jurisdictions requires some form of participation in the planning process, the type of participation is open to interpretation and policy guidance in this vital area is lacking. A multi-disciplinary team lead by Griffith University carried out two national research projects to examine barriers and enablers to active involvement, otherwise termed collaboration in water planning, and to develop means of improved collaboration.

In the Murray-Darling Basin, the proposed development of a new cap on consumptive use based on sustainable yield through a Basin Plan [2] resulted in community backlash when a Plain English Guide to the plan was circulated. Subsequently, a Parliamentary committee enquiry into the planning process called for improved engagement with local communities [3]. Termed "localism" by the media and others, this approach and the enquiry's recommendations have been accepted by the Australian government [4].

This article examines the approach of "localism" and places it within theoretical constructs of participation. It provides a synopsis of the results in two research projects and examines the challenges faced by water planners in implementing participation. The lessons from this research may be useful in other planning contexts especially where the science in contested, social values are uncertain and communities are diverse.

\section{Participation and "localism" as planning approaches}

There has been a worldwide shift towards greater community participation in spheres such as environmental decision-making and natural resource management. Involving local people in the management of resources upon which their livelihoods depend is seen to be giving them "ownership" or a stake in the sustainable use of those resources.

A series of international declarations on water management have endorsed the participatory approach and have combined it with the principle of subsidiarity. Adopted by the European Union's (EU) Maastricht Treaty, subsidiarity embodies the idea that decisions within a political system should be made at the lowest level unless there are compelling reasons otherwise. The locus of decision-making therefore is devolved to the local level, whereas higher-level institutions are charged with general policy making or regional strategies. Initially, this principle only applied in the relationships between the EU and the member states, but its application has been extended beyond the EU.

Participatory approaches have adopted in Australia particularly in natural resource management (NRM) because it was seen to be suitable for systems that are complex, occurring at various scales, and requiring information from different disciplines and sources. In Australian NRM, public participation processes are usually government initiated. Because of the commitment of large 
public expense, the authority and responsibility for decisions is frequently the relevant Minister.

To understand the place of "localism" within the various constructs of participation, it is helpful to examine the large body of literature on the subject, see for example the review in Reed [5].

Four typologies exist, of which Arnstein's ladder of participation is the most widely known [6]. Based on different degrees of participation on a continuum, participation is placed on a "ladder" that ranges from non- participation (manipulation and therapy) at the bottom, to tokenism (information giving and consultation) as middle rungs, to the top rungs of delegation of decision-making and citizen control. Arnstein's argument is that participation can encompass a range of processes in which people act collectively for a purpose, but that the most effective form of participation is when they acquire power, autonomy and resources in the process.

Another typology refers to the direction of information flow: with one way termed "communication" where information is given to passive recipients and "consultation" is one way information gathered from participants; and "participation" is a two-way exchange.

The third typology relates to the theoretical basis of participation, differentiating a normative (participation should be carried out for reasons of democratic emancipation, equity and social justice) from a pragmatic justification. The fourth typology is based on objectives for which participation is used.

Each of these typologies informs the selection of methods that are most appropriate in a given context $[5,7]$. Table 1 below provides how modes or types of participation may be aligned with objectives to be achieved, and provides some examples of the methods that may be adopted.

\section{Participation in Australian water planning}

The 2004 NWI seeks to establish nationally consistent principles for reform including trading of water. The NWI emphasises that future decision-making needed to optimise "economic, social and environmental outcomes" through transparent, statutory water planning which targets amongst other things, "the return of all currently overallocated or overused systems to environmentallysustainable levels of extraction" and addresses future adjustment issues that may impact on water users and communities [1] clause 23. Water planning is the main mechanism for achieving objectives of reform.

Australian water planning follows the NRM model where the Minister is the decision maker and national water policy documents have adopted a pragmatic, objective-based approach to participation. The first national water policy document [8] specifically required public consultation in relation to water allocation and trading, while the NWI [1] required "open and timely consultation" with participation required to improve certainty and build confidence in reform processes, provide transparency in decision-making, and ensure sound information at key decision points. 
Table 1: $\quad$ Modes, objectives and methods of participation [7].

\begin{tabular}{|c|c|c|}
\hline Mode & Objectives & Methods of Participation \\
\hline $\begin{array}{l}\text { Information } \\
\text { provision }\end{array}$ & $\begin{array}{l}\text { To provide the public with } \\
\text { balanced and objective } \\
\text { information to assist them in } \\
\text { understanding the problems, } \\
\text { alternatives and solutions }\end{array}$ & $\begin{array}{l}\text { Leaflets, brochures, mailings, } \\
\text { information centres, media, } \\
\text { field trips, briefings, contact, } \\
\text { websites }\end{array}$ \\
\hline Consultation & $\begin{array}{l}\text { To obtain public feedback } \\
\text { on analysis, alternatives and } \\
\text { decisions }\end{array}$ & $\begin{array}{l}\text { Written submissions, public } \\
\text { hearings, interviews, focus } \\
\text { groups, reply forms, opinion } \\
\text { polls, advisory groups, } \\
\text { Delphi Study, surveys, } \\
\text { photo-voice, structured } \\
\text { observations, expert panels }\end{array}$ \\
\hline Collaboration & $\begin{array}{l}\text { To work together with the } \\
\text { public and establish spaces } \\
\text { for dialogue and deliberation } \\
\text { (e.g. water planning } \\
\text { committees, community } \\
\text { reference panels), to agree } \\
\text { on decision-making criteria, } \\
\text { assist in development of } \\
\text { alternatives and the } \\
\text { identification of a preferred } \\
\text { solution }\end{array}$ & $\begin{array}{l}\text { Workshops, round-tables, } \\
\text { planning cells, study circles, } \\
\text { citizen juries, working } \\
\text { groups, MCA, GIS } \\
\text { techniques, charrettes, } \\
\text { scenario evaluation, values } \\
\text { mapping, citizen- } \\
\text { science/action research, } \\
\text { consensus conferences, } \\
\text { formal negotiations, } \\
\text { management agreements, } \\
\text { community reference panels, } \\
\text { stakeholder representation, } \\
\text { mediation, data or cost- } \\
\text { sharing agreements }\end{array}$ \\
\hline $\begin{array}{l}\text { Partnership } \\
\text { and citizen } \\
\text { control }\end{array}$ & $\begin{array}{l}\text { To re-negotiate power } \\
\text { within the collaborative } \\
\text { relationship between } \\
\text { government and the public } \\
\text { to one of power sharing. } \\
\text { This re-negotiation may } \\
\text { even involve devolving final } \\
\text { decision-making power into } \\
\text { the hands of the public }\end{array}$ & $\begin{array}{l}\text { Devolved public functions } \\
\text { e.g. citizen initiatives }\end{array}$ \\
\hline
\end{tabular}

Overallocation and environmental stress in the Murray-Darling Basin (Basin) is a main driver of national policy. In the Basin more than twice the annual flow is held in storage and about $75 \%$ of the mean annual flow is diverted mostly for 
irrigation. Water planning needs to recover large volumes of water for the environment, ranging from 3,000 to 4,000 GL per year [2]. This has recently been reduced to $2,750 \mathrm{GL}$ in a revised draft of the proposed Plan currently in the last stages of formulation [9].

When the Australian Parliament examined public participation processes undertaken for the Draft Basin Plan it endorsed an approach that went beyond formal feedback and consultation, and provided for collaboration and deliberation (or active involvement) on aspects of the plan. The Report, after considering public hearings and written submissions noted that

.... the Basin Plan will only be successful, if developed with a community engagement strategy that is focused on transparency of process and contains clear and meaningful opportunities for local communities to contribute to and take ownership of the final Plan [3, para 4.16].

...it is essential to have a localised approach to planning ... [3, para 4.31]

With reference to the modes and objectives of participation shown in Table 1 above, this local engagement required by the Parliamentary Report would arguably fit within the "collaboration" mode.

Collaboration or active involvement refers to interaction between decision makers and the public to deliberate potential decision options, agree on decisionmaking criteria, assist in developing alternate options, and identify a preferred option. Methods are adopted that provide opportunities for debate and dialogue however they do not necessarily lead to agreement between parties on an issue. Effective dialogue does however lead to greater clarity and understanding between each party's position and the underlying values [10]. Such processes have been long recognised by practitioners as helpful in contexts such as urban planning and healthcare $[11,12]$.

\section{Communities actively involved in water planning}

Active involvement by communities is difficult to achieve even in welldeveloped European countries [13] and its benefits are not always well documented [5]. In Australia, water planners generally tend to use fairly traditional participatory techniques. For example facilitated community meetings or community panels are often used, even though there are a wide range of possible methods [7, 14]. Planners see sustainable management as being difficult to achieve with community participation because of a long history of conflict in many overallocated catchments.

Research into participatory approaches to water planning was carried out in two projects [15]. In project 1 the team conducted evaluations of water planning processes in Northern Australia, focusing on the Gulf of Carpentaria in Queensland and the Ord in Western Australia [16, 17]. Over sixty interviews were conducted to identify barriers and enablers to collaboration. We then 
worked with the Northern Territory water agency in a groundwater planning process in Howard East, a region outside Darwin [18].

In project 2, using a participatory action methodology, we combined a research focus which embedded good process into developing a range of engagement tools that could be readily used by water planners [19]. The study regions were the River Murray, South Australia; the Condamine Alluvium, Queensland; and the Tiwi Island, Northern Territory. We prioritised areas of concern through stakeholder, context and issues analyses. Then with water planning agencies we developed a series of tools which could then be evaluated using indicators for four different criteria: good process; technical quality; stakeholder outcomes; and water planning outcomes [7].

We developed fit for purpose tools that addressed water planning challenges found in the three case-study areas. These are shown in Table 2 below.

In line with international approaches calling for adaptive management of complex natural resource systems we advocate the use of an adaptive management framework to support local and community involvement in these challenges and opportunities (fig. 1).

Table 2: Tools developed to address identified challenges in case-study regions [7].

\begin{tabular}{|l|l|}
\hline Challenges & Addressed by Project \\
\hline $\begin{array}{l}\text { Addressing } \\
\text { overallocation and } \\
\text { achieving ecological } \\
\text { sustainability }\end{array}$ & $\begin{array}{l}\text { Planning in the context of overallocation addressed. } \\
\text { Wetland watering in periods of scarcity prioritised. } \\
\text { Intergenerational equity workshops with secondary } \\
\text { school students. }\end{array}$ \\
\hline $\begin{array}{l}\text { Improving community } \\
\text { engagement }\end{array}$ & $\begin{array}{l}\text { Variety of innovative engagement mechanisms } \\
\text { trialled. } \\
\text { Indigenous social, spiritual and customary values } \\
\text { identified. } \\
\text { Indigenous engagement tools for a variety of } \\
\text { contexts trialled. }\end{array}$ \\
\hline $\begin{array}{l}\text { Building community } \\
\text { confidence in planning }\end{array}$ & $\begin{array}{l}\text { Tools compared and evaluated for good process, } \\
\text { technical quality, stakeholder learning and planning } \\
\text { outcomes. } \\
\text { Education and engagement tools built by } \\
\text { independent scientists and service providers. } \\
\text { Tools developed that can embrace complexity and } \\
\text { provide an instantaneous record of discussions. }\end{array}$ \\
\hline $\begin{array}{l}\text { Achieving distributional } \\
\text { equity }\end{array}$ & $\begin{array}{l}\text { Demonstrated transparency in trade-offs through } \\
\text { deliberative multi-criteria evaluation. } \\
\text { Water users' surveys to assess values and } \\
\text { preferences for trade-offs designed and tested. } \\
\text { Better understanding of impacts of options through } \\
\text { socio-economic impact assessment. }\end{array}$ \\
\hline
\end{tabular}


Table 2: $\quad$ Continued.

\begin{tabular}{|l|l|}
\hline Challenges & Addressed by Project \\
\hline $\begin{array}{l}\text { Improving risk and } \\
\text { impact assessments }\end{array}$ & $\begin{array}{l}\text { Risk assessment principles for water planning } \\
\text { context developed. } \\
\text { A range of possible future scenarios including } \\
\text { impacts on socio-economic and cultural values } \\
\text { considered. } \\
\text { Multi-criteria assessment across multiple decision- } \\
\text { making contexts demonstrated. }\end{array}$ \\
\hline $\begin{array}{l}\text { Dealing with uncertainty } \\
\text { and change }\end{array}$ & $\begin{array}{l}\text { Climate change impacts on availability and demand } \\
\text { considered in water planning at farm and catchment } \\
\text { scales. } \\
\text { Social impacts in scenarios of reduced flows } \\
\text { assessed. } \\
\text { Adaptive management framework modified and } \\
\text { improved through implementation guidelines. }\end{array}$ \\
\hline Building in adaptability & $\begin{array}{l}\text { Monitoring and evaluation assessments for water } \\
\text { plans developed to include process, content and } \\
\text { outcome criteria. } \\
\text { Social impacts in scenarios of reduced flows } \\
\text { assessed. }\end{array}$ \\
\hline $\begin{array}{l}\text { Providing the needed } \\
\text { human resources }\end{array}$ & $\begin{array}{l}\text { developed and promoted. } \\
\text { Knowledge needs and information gaps identified for } \\
\text { training purposes. } \\
\text { Tools with capacity building components for } \\
\text { planners and land rangers trialled. }\end{array}$ \\
\hline $\begin{array}{l}\text { Encouraging trade and } \\
\text { specification of water } \\
\text { entitlements }\end{array}$ & $\begin{array}{l}\text { Baseline information for the effective design of } \\
\text { trading mechanisms (supply and demand } \\
\text { assessments) acquired. }\end{array}$ \\
\hline $\begin{array}{l}\text { Integration with natural } \\
\text { resource management } \\
\text { and urban planning }\end{array}$ & $\begin{array}{l}\text { Evidence and information base for alignment of } \\
\text { natural resource management, environmental water } \\
\text { management and water planning integrated. }\end{array}$ \\
\hline
\end{tabular}

Additionally, two workshops were held for water planners. With key state government partners at an early stage of Project 2, we investigated a range of tools for improving the quality of socio-economic assessment for two of the study areas: the Condamine Alluvium and South Australian Regulated River Murray. This two-day workshop involved experts presenting a range of methods for consideration by planners. At the end of Project 2, planners reviewed research findings at a national workshop. In affirming research results, the participants underscored the importance of community engagement and how water planning needs to deliver the statutory objective of environmental sustainability. 


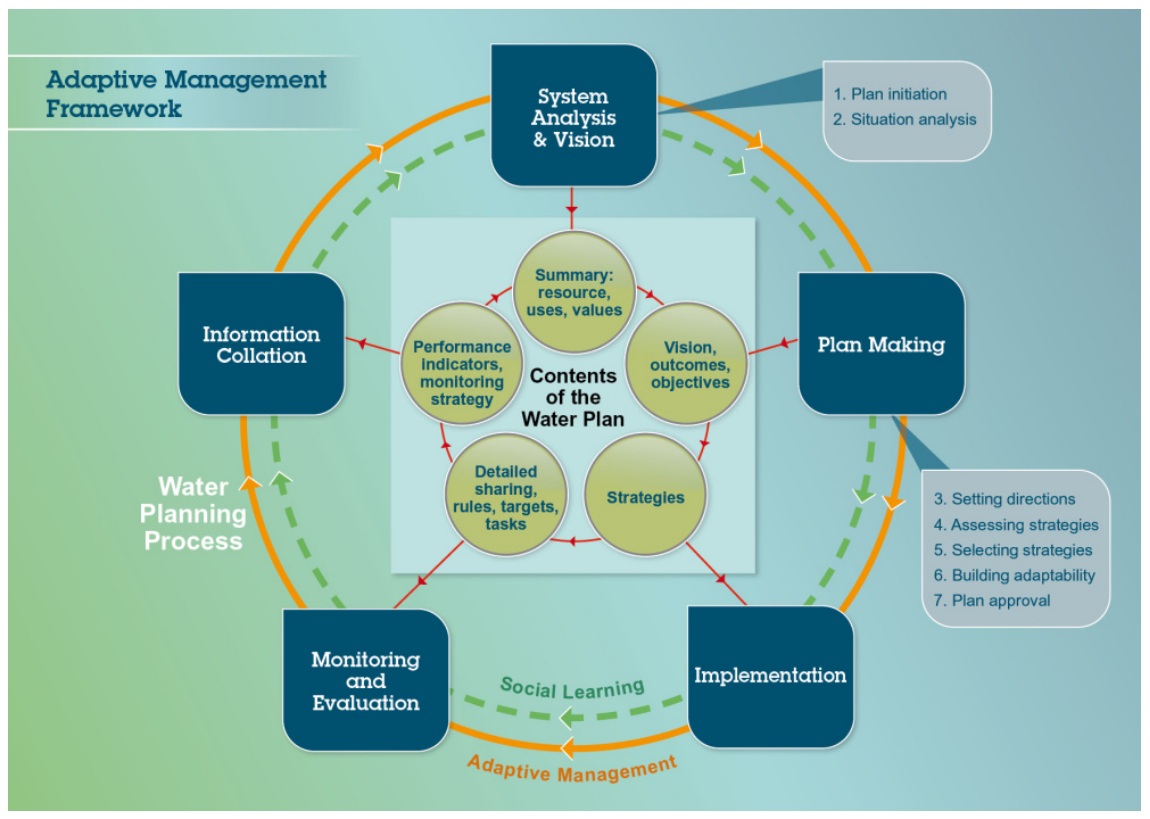

Figure 1: $\quad$ Adaptive management framework [7].

\section{Lessons and limitations of the research}

Many of the lessons recorded below are already well known, however our results record and confirm the benefits of participatory processes, provide indicators for measuring successful use and note that implementation remains a key challenge. The key lessons are:

1. The purpose of participation needs to be clear and relevant to the stakeholders. When the purpose is solely to give information to stakeholders and the general community, groups are reluctant to put time and effort into the process. Many groups already demonstrate "consultation fatigue" and are reluctant to participate, distrusting government processes.

2. Understanding the need for cut-backs in human use requires social learning as observed in our study in the Queensland [20] and South Australia [21]. Several complementary factors are identified as fundamental to social learning including the ability to negotiate and agree on rules and roles, strong leadership and facilitation, and 'triple-loop' learning processes that enable the questioning of assumptions and the reconsideration of beliefs and values. It is this aspect of social learning that deliberative processes address [22].

3. 'Best available science' needs to be accessible. Where the science is uncertain, or where communities query the science, collaborative problem solving may provide solutions, or at the very least, narrow the range of uncertainty [23]. 
4. Indigenous engagement requires a sensitive and targeted approach requiring a longer time period and culturally appropriate methods [24]. Currently Indigenous values are viewed as lacking contemporary influence. We note that while Indigenous water reserves and innovative methods are more readily accepted in Northern Australia where there is less competition for water, Indigenous Australians in overused catchments struggle to find recognition of their interests and values in water.

5. A participatory approach for engaging local communities, addressing specific areas of concern, giving access to independent scientists, using interactive and visual methods that provide an instantaneous record of conversation has been demonstrated as building community confidence in the process of water plans [22]. Evaluations in the Howard East study show one example of confidence building, and how this was measured [18].

\section{Conclusions}

The research records how well-constructed deliberative processes, formulated with planners, carried out early in the planning process and targeted towards specific questions where community input is vital, have the potential to shift entrenched interests and reach an agreed position, even if total consensus is not available. This could be how "local" views could be elicited for planning purposes.

As noted by the current chair of the Murray-Darling Basin Authority, local involvement is critical to develop options and find trade-offs for achieving ecosystem resilience in the face of increasing demand for water combined with climate variability and change. Many deliberative processes targeted to engage local communities have been used in other public problem-solving contexts, but generally planners are reluctant to apply them in water planning or lack the appropriate skills. It is critical that governments build capacity to apply participatory processes especially when past history and recent events confirm their efficacy.

Implementation of scientifically credible, transparent and collaborative water planning processes will build community confidence in water plans and lead to improved management for maintaining sustainable river ecosystems. Especially where water is over-allocated and competition is high, it remains a challenge to use 'best available' information in a way that feeds into the processes of planning.

\section{Acknowledgements}

This work draws from two projects. The Collaborative Water Planning Project (2007-2009) was funded through the Tropical Rivers and Coastal Knowledge research hub which brings together leading tropical river researchers and managers from a group of universities and institutions. TRaCK received major funding or its research through the Australian Government's Commonwealth Environment Research Facilities initiative; the Australian Government's Raising 
National Water Standards Programme; Land and Water Australia and the Queensland Government's Smart State Innovation Fund. The Water Planning Tools project (2008-2010) was funded by the National Water Commission through its Raising National Water Standards Program which supports community members, stakeholders and water planners participated in the research and we thank them for their patience, ideas, and generous contribution of their time.

\section{References}

[1] Council of Australian Governments. Intergovernmental Agreement on a National Water Initiative. Canberra. 2004. http://www.nwc.gov.au/www/ html/117-national-water-initiative.asp

[2] Murray-Darling Basin Authority. Guide to the Proposed Basin Plan, Canberra, 2010.

[3] House of Representatives, Standing Committee on Regional Australia, Of Drought and Flooding Rains: Inquiry into the Impact of the Guide to the Murray-Darling Basin Plan. Parliament of the Commonwealth of Australia, Canberra, 2011.

[4] Government of Australia. Australian Government Response to the House of Representatives Standing Committee on Regional Australia's Report: Of Drought and Flooding Rains: Inquiry into the Impact of the Guide to the Murray-Darling Basin Plan. Commonwealth Government, Canberra, 2011.

[5] Reed, M., Stakeholder participation for environmental management: A literature review. Biological Conservation 141, pp. 2417-2431, 2008.

[6] Arnstein, S. R., A Ladder of Citizen Participation. American Institute of Planners, 35(2), pp. 216-24, 1969.

[7] Tan, P-L., Mooney, C., White, I., Hovermann, S., Mackenzie, J., Burry, K., Baldwin, C., Bowmer, K., Jackson, S., Ayre, M., and George, D., Tools for Water Planning, Lessons, Gaps and Adoption. Waterlines, National Water Commission, 2010.

[8] Council of Australian Governments. Water Reform Framework. Canberra, 1994. $\quad$ http://www.environment.gov.au/water/publications/action/pubs/ policyframework.pdf.

[9] Murray-Darling Basin Authority. The proposed Basin Plan - A revised draft. Canberra, 2012.

[10] Yankelovich, D., The Magic of Dialogue: Transforming Conflict into Cooperation. Simon \& Schuster, New York, 1999.

[11] Forester, J., The Deliberative Practitioner: Encouraging Participatory Planning Processes. MIT Press, Cambridge, 1999.

[12] Abelson, J., Forest, P.G., Eyles, J., Smith, P., Martin, E., and Gauvin, F.P., Deliberations about deliberative methods: issues in the design and evaluation of public participation processes. Soc. Sci. and Med. 57(2), pp. 239-251, 2003. 
[13] van der Heijden, J, and ten Heuvelhof, E., The Mechanics of Virtue: Lessons on Implementing the Water Framework Directive in the Netherlands, Env Pol. Gov, 22, pp. 177-188, 2012.

[14] Hamstead, M., Baldwin C., and O'Keefe, V., Water Allocation in Australia. Current Practices and Lessons Learned, Waterlines, National Water Commission, 2008.

[15] Tan, P-L, Bowmer, K., and Mackenzie J, Deliberative Tools for Meeting the Challenges of Water Planning in Australia, Journal of Hydrology, in press, http://dx.doi.org/10.1016/j.jhydrol.2012.02.032.

[16] Ayre, M., Collaborative Water Planning: Retrospective Case Studies: Water planning in the Ord River of Western Australia, Volume 4.2. Report to the Tropical Rivers and Coastal Knowledge (TRaCK) program, Land \& Water Australia, Canberra, 2008.

[17] Mackenzie, J., Collaborative Water Planning: Retrospective Case Studies: Water Planning in the Gulf of Carpentaria, Volume 4.1. Report to the Tropical Rivers and Coastal Knowledge (TRaCK) program, Land \& Water Australia, Canberra, 2008.

[18] Jackson, S., Tan, P-L, and Nolan, S., Tools to enhance public participation and confidence in the development of the Howard East aquifer water plan, Northern Territory. Journal of Hydrology, in press, http://dx.doi.org/10.1016/j.jhydrol.2012.02.007.

[19] Mackenzie, J., Tan, P-L., Hoverman, S., and Baldwin, C., The Value and Limitations of Participatory Action Research Methodology. Journal of Hydrology, in press, doi: http://dx.doi.org/10.1016/ j.jhydrol.2012.09.008.

[20] Tan, P-L, Baldwin, C, White, I., and Burry K., Addressing overallocation in the Condamine Alluvium in Queensland. Journal of Hydrology, in press, http://dx.doi.org/10.1016/j.jhydrol.2012.01.004vn

[21] Mooney, C., and Tan P-L., South Australia's River Murray water planning: contestation and complexity. Journal of Hydrology, in press, http://dx.doi.org/10.1016/ j.jhydrol.2012.04.010.

[22] Mooney, C., Mackenzie J., Tan, P-L., and Baldwin, C., Transparency and trade-offs in water planning. Journal of Hydrology, in press. http://dx.doi.org/10.1016/ j.jhydrol.2012.06.040.

[23] Baldwin C., Tan, P-L., White, I., Hoverman, S., and Burry, K., How scientific knowledge informs communities' understanding of groundwater. Journal of Hydrology, in press.

[24] Jackson, S., Tan, P-L, Mooney, C., Hoverman, S., and White, I, Principles and guidelines for good practice in Indigenous engagement in water planning. Journal of Hydrology, in press, http://dx.doi.org/10.1016 /j.jhydrol.2011.12.015. 